\title{
INVESTIGATION OF MEDICAL- AND WELLNESS TOURISTS OF A HUNGARIAN SPA TO EXPLORE RELATIONSHIPS BETWEEN SERVICE QUALITY, CUSTOMER SATISFACTION AND LOYALTY
}

\author{
Zsuzsanna LŐKE
}

University of Pannonia Georgikon Faculty, Department of Economics, Social Sciences and Rural Development, Keszthely, Deák Ferenc str. 16. 8360-Hungary email: loke@georgikon.hu

Cite this article: Löke, Z. (2020). Investigation of Medical- and Wellness Tourists of a Hungarian Spa to Explore Relationships Between Service Quality, Customer Satisfaction, and Loyalty. Deturope, 12(1), 102-118.

\begin{abstract}
Good quality services mean an advantage in competition; they help to keep old guests and to receive new ones. For a provisional enterprise, guest satisfaction is not only an objective but also an effective marketing tool, knowing that the repeated purchases and recommendations of a satisfied, loyal customer can be very effective marketing methods. But does high quality of services and satisfaction really guarantee the loyalty of spa guests? In order to receive an answer to this, we have questioned 300 Hungarian guests of Hévíz Spa in the dimensions of service quality, satisfaction and loyalty. We have evaluated the replies of 164 medical guests and 117 wellness tourists separately. The positive relationship between quality and satisfaction has been confirmed both in case of medical- and wellness tourists. In the case of medical tourism, the significant positive relationship between the loyalty dimensions of willingness to return, recommendation willingness and positive word-advertising has also been proven. In the case of wellness tourists, however, satisfaction and loyalty relations are less obvious. Regression analysis draws our attention to the key role of pleasure and satisfaction dimension, directing spa services towards providing joyful experiences! According to this research, we can also determine, that measuring customer satisfaction is not enough, as other factors affecting the loyalty of medical- and wellness tourists also have to be explored.
\end{abstract}

\section{INTRODUCTION}

\section{Service Quality}

Lewis and Booms (1983) were among the first researchers to define service quality as a measure of correspondence between provided service and customer expectations. Among the several authors dealing with the subject, Kenesei and Kolos (2007) defines service quality as the difference between customer expectations and experience, where "the more customer experiences excess preliminary expectations, the higher is the perceived quality". Veres (2009), in the essential manual of service marketing, draws our attention that quality can only be generalized to a limited extent, as it is also influenced by subjective factors, has some immeasurable parameters, and differences can occur between the opinion about general service 
quality and about a specific occasion. Moreover, as Grönroos (1998) reminds us since, in the case of services, we talk about "process consumption", the perceived quality is constructed from the dimensions of technical quality and functional performance. The recipient perceives both quality dimensions. However, since sometimes technical quality cannot be discerned, functional performance, namely the way the given service is provided (kindness, speed, cooperation with the customer) has a high level of influence on the overall quality image. In case of services provided in the direct presence of the guest - like medical touristic services provided in spas - perceived quality is not only influenced by service results, but also by the whole of the service process (Al-Alak \& EL-Refae, 2012). No wonder that in certain service areas, some enterprises emphasize this functional performance, thus gaining an advantage in competition with these unique characteristics that cannot be easily copied.

In tourism - similarly to other sectors - the stronger the competition is, the more the measuring and development of service quality are in focus (Škodová Parmová, Dvořáková Líšková, \& Kain, 2018, Lőke, Kovács \& Bacsi, 2018). Research of service quality has become an individual branch of marketing in the 1980s since professionals considered quality improvement as a key factor in gaining success. In the subject of service quality research, the studies of Parasuraman, Zeithaml, and Berry (1985) and the synoptic works of Brown et al. (1991) are some of the most well-known sources. In the course of investigating the factors influencing the level of perceived quality, Parasuraman, Zeithaml, and Malhotra (2005) have identified 10 factors, eight of these belonging to this previously discussed dimension defined as functional performance, thus reinforcing the relevance of this element. In the original and modified SERVQUAL method, used in a wide range of services - in the spheres of commerce, hygiene, education, tourism - the number of these quality factors was reduced to five (1. reliability, 2. security, 3. tangibility, 4. helpfulness, 5. empathy). In order to measure service quality, recipients have to evaluate 22 statements linked to the above mentioned five factors, on a Likert scale.

\section{Satisfaction}

„Satisfaction reflects the customers' comparative judgements about perceived performance of the product according to their respective experiences." (Kotler \& Keller, 2012). In other words, how much does it satisfy customer expectations? Does it fill the recipient with satisfaction, or contrarily, does it cause disappointment? (Zeithaml, Berry, \& Parasuraman, 1988; Fisk, Brown, 
\& Bitner, 1993; Kotler \& Keller, 2012) And if it exceeds expectations, the customer will be excessively satisfied, or in another way, the recipient is going to be happy. Thus, in general, satisfaction is the joy or disappointment created as a result of expected and received services.

From the investigations of Anderson, Fornell, \& Lehmann (1994), Cronin \& Taylor (1992) we know, that the higher the recipients perceive service quality, the more satisfied they will be, however, "it is not about an objective quality, but about quality perceived by the customer, which of course can vary according to different consumers" (Simay, 2013:26). Satisfaction is an indicator of the consumer-oriented nature of the enterprise. Thus its systematic measurement is necessary. No wonder that a large number of empirical researches have been directed towards service quality-customer satisfaction-willingness to repurchase relations (Cronin, Brady, \& Hult, 2000; Tian-Cole, Crompton, \& Willson, 2002; Lee, Kim, \& Sagas, 2011).

Customer satisfaction is not only a purpose for a foresighted enterprise, but also an effective marketing instrument, since by the help of the internet, the positive or on the contrary, the negative reputation of the company can spread around quickly (Kotler \& Keller, 2012). Nowadays, customers became active proclaimers of their opinion by the help of internet. The recipients share their experiences on the World Wide Web, and the question is not that a certain complaint is well-founded or not, but instead "How much damage can a dissatisfied customer cause?" On the other hand, how much profit can be gained by the positive verbal advertisements of satisfied customers? Verbal advertisement, "word-of-mouth (WOM) always had an important role in the sharing of experiences about the purchase of a product or a service" (Nagy et al. 2015), and today's e-WOM (electronic-word-of-mouth) reaching out to remarkably wide audiences also have several forms, among which blogs are especially popular in the sphere of tourism. Due to their intangible nature, the purchase of services is more risky than buying physical products, and it is hard to get to know them beforehand - for a real judgement, experience is needed - so it is especially true that customers try to gain knowledge from the experiences of others. Owing to modern technical development, the internet offers new online alternatives of face-to-face relationships, which can be "double-edged weapons", so a service provider has to pay proper attention to these (Kaya, 2018). "WOM can be positive or negative. Positive WOM may include making recommendations about a product or service, and informing others of the quality of an offer.” (Kumar, Pozza, \& Ganesh, 2013:251). Word of mouth usually has more credit - as it reports about respective experiences - and thus it is more effective than traditional forms of advertisement (Csordás, Markos-Kujbus, \& Ásványi, 2018). 
Unfortunately however, positive word of mouth spreads with less efficiency than negative opinions. According to this, a token of the long-term subsistence of an enterprise is the satisfied customer, enforcing the positive reputation of the company.

\section{Loyalty}

We can perceive loyalty as some kind of commitment, faithfulness, and fidelity. „Faithful and satisfied customers are instruments of income production for the enterprise" (Anderson, Fornell, \& Lehmann, 1994:63). An especially satisfied customer makes purchases more often, is less price-sensitive, pays less attention to concurrent offers, can be served more easily on the grounds of the existing relationship than a new customer, can suggest new ideas for development and can spread positive news about the company (Zeithaml, 2000; Kotler \& Keller, 2012). The correlation between satisfaction and loyalty, however, is not proportional. Although there is an existing quality-satisfaction-loyalty correlation, satisfaction still does not necessarily result in customer loyalty. Oliver (1999) and Hetesi (2002) warn us about how far satisfaction-loyalty correlations are from being unambiguous in the light of several researches. Satisfaction does not necessarily result in loyalty, and even a dissatisfied client can be loyal. According to the behaviour of customers, Jones and Sasser (1995) distinguished loyalist, defector, mercenary and hostage types (Tab. 1).

Table 1 Individual Customer Satisfaction, Loyalty, and Behavior

\begin{tabular}{|l|l|l|l|}
\hline & Satisfaction & Loyalty & Behavior \\
\hline Loyalist/Apostle & high & high & staying and supportive \\
\hline Defector/Terrorist & low to medium & low to medium & $\begin{array}{l}\text { leaving or having left and } \\
\text { unhappy }\end{array}$ \\
\hline Mercenary & high & low to medium & $\begin{array}{l}\text { coming and going; low } \\
\text { commitment }\end{array}$ \\
\hline Hostage & low to medium & high & unable to switch; trapped \\
\hline
\end{tabular}

Source: Jones and Sasser (1995)

Hetesi (2003) in his synthetic work deploys both studies substantiating significant positive quality-satisfaction-loyalty relations (Grönholdt, Martensen, \& Kristensen, 2000; Martensen, Grönholdt, \& Kristensen, 2000), and research results, where extensive satisfaction is not consorted by loyalty (Jones \& Sasser, 1995; Reicheld \& Sasser, 1990; Reicheld, 1996; Vollmer et al., 2000). Due to its direct effects on profitability, the investigation of the correlations 
between customer contentment and loyalty is important for every leader. The significance of the subject is proven by the vast number of researches conducted about contentment-loyalty correlations, not only in the area of tourism (Canny, 2013, Khan, Yusoff, \& Kakar, 2017), but also in casinos, (Bilgihan, Mandanoglu, \& Ricci, 2016), preferential retail trade (Powers, Jack, \& Choi, 2019), financial sector (Trif, 2013), and insurance companies (Picón, Castro, \& Roldán, 2014).

The distinction between earned and purchased loyalty is also emphasized by Edvardsson et al. (2000): loyalty can be earned by good quality and by delivering values. Purchased loyalty however, results in short-term repurchase by sales promotions (coupons, discounts), which are used by the recipients, but upon finding a more favourable offer they turn over to it. Thus, purchased loyalty does not last long, however, still can be used for the outplacement of other competitors (Cheverton, 2005).

\section{OBJECTIVES AND METHODS}

As a primary method of investigation, I have chosen the method of structured direct survey of descriptive researches, as this method provides the opportunity to ask several questions at the place of requisition of services (in our case among the guests of Hévíz Spa, located in Hungary). The survey was conducted between 27 February and 31 March 2017. The survey sample was divided to two parts: $50 \%$ was surveyed in the Pool Bath and 50\% in the Thermal Lake, questioning altogether 300 customers - patients and guests. The questionnaires were administered by 13 interviewers - university students specialised in tourism studies. The survey contained: questions about three satisfaction- (E1-E3) and four loyalty dimensions (L1-L4) (Tab. 2), and also a version of SERVQUAL questionnaire developed for measuring service quality by Parasuraman, Zeithaml, \& Malhotra (2005) adapted to spa services (Lőke, Kovács, \& Bacsi, 2018). Each of these questions had to be answered on a five-stage Likert scale. The survey included questions concerning the motivations and the demographical characteristics of the respondent.

Table 2 Investigated quality-satisfaction-loyalty dimensions in the survey 
Lőke, Z.

\begin{tabular}{|c|c|c|c|c|c|c|}
\hline \multirow{2}{*}{\multicolumn{2}{|c|}{ Survey Question }} & \multicolumn{5}{|c|}{ Verbalized 5-stage Likert scale values } \\
\hline & & 1 & 2 & 3 & 4 & 5 \\
\hline 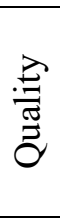 & $\begin{array}{l}\text { SERVQUAL questions adapted to a spa. } \\
\text { Please evaluate how do you consider the } \\
\text { performance of the Hévíz Spa in the } \\
\text { range of the given quality } \\
\text { characteristics! }\end{array}$ & bad & suffice & mediocre & good & $\begin{array}{l}\text { very } \\
\text { good }\end{array}$ \\
\hline \multirow{3}{*}{ 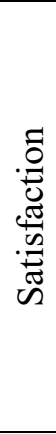 } & $\begin{array}{l}\text { E1. How much do you agree that your } \\
\text { preliminary expectations towards the } \\
\text { service provider are fulfilled? }\end{array}$ & \multirow{2}{*}{$\begin{array}{l}\text { absolutely } \\
\text { disagree }\end{array}$} & \multirow{2}{*}{$\begin{array}{l}\text { rather } \\
\text { disagree }\end{array}$} & \multirow{2}{*}{$\begin{array}{l}\text { both } \\
\text { agree and } \\
\text { disagree }\end{array}$} & \multirow{2}{*}{$\begin{array}{l}\text { mostly } \\
\text { agree }\end{array}$} & \multirow{2}{*}{$\begin{array}{l}\text { complete } \\
\text { ly agree }\end{array}$} \\
\hline & $\begin{array}{l}\text { E2. How much do you agree that the time } \\
\text { spent at the Hévíz Spa was a pleasure }{ }^{2} \\
\text { to you? }\end{array}$ & & & & & \\
\hline & $\begin{array}{l}\text { E3. According to overall impressions, } \\
\text { how satisfied are you with the Spa? }\end{array}$ & $\begin{array}{c}\text { very } \\
\text { dissatisfied }\end{array}$ & $\begin{array}{c}\text { mildly } \\
\text { dissatisfi } \\
\text { ed }\end{array}$ & $\begin{array}{c}\text { I } \\
\text { consider } \\
\text { it } \\
\text { sufficient }\end{array}$ & $\begin{array}{c}\text { I } \\
\text { consider } \\
\text { it good }\end{array}$ & Excellent \\
\hline \multirow{3}{*}{ 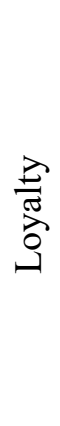 } & $\begin{array}{l}\text { L1. What is the possibility of a return to } \\
\text { the spa or the medical lake of Hévíz Spa? } \\
\text { L2. What is the possibility of } \\
\text { recommending Hévíz Spa to your friends } \\
\text { or family? }\end{array}$ & \multirow{3}{*}{$\begin{array}{c}\text { very } \\
\text { unlikely }\end{array}$} & \multirow{3}{*}{$\begin{array}{l}\text { probably } \\
\text { won't }\end{array}$} & \multirow{3}{*}{$\begin{array}{l}\text { maybe, } \\
\text { but not } \\
\text { sure }\end{array}$} & \multirow{3}{*}{ probably } & \multirow{3}{*}{$\begin{array}{c}\text { very } \\
\text { probably }\end{array}$} \\
\hline & $\begin{array}{l}\text { L3. What is the possibility of reporting } \\
\text { positively to others about Hévíz Spa? }\end{array}$ & & & & & \\
\hline & $\begin{array}{l}\text { L4. What is the possibility of } \\
\text { complaining to others if you'd have } \\
\text { problems with the services? }\end{array}$ & & & & & \\
\hline
\end{tabular}

Source: Author's own results

Evaluation was done by SPSS 22. statistical program. For analysis, I used simple descriptive statistics, frequency distributions, while the correlational investigation of data series was done by correlation-calculation and regression analysis (with forward method). As a preliminary examination for correlation calculation, I have verified with the help of boxplot whether there are any salient data. For the evaluation, the works of Sajtos and Mitev (2007), Hofmeister Tóth, Simon, \& Sajtos (2003) and Malhotra (2002) were also used.

\section{Introduction of the research sample and the dual clientele of the Spa}

The location of the investigation, Hévíz Spa and St. Andrews Rheumatic Hospital has a dual clientele since it was founded in 1952. The medicinal water prescribed for musculoskeletal and rheumatic diseases has contributed to the healing or to the easing of the symptoms of many patients (Bacsi \& Kovács, 2016). However, apart from medicinal tourists, the 4 hectares of worthily unique thermal water of the Thermal Lake at Hévíz, whose water temperature can be as high as $38^{\circ}$ in the summer and is never below $22^{\circ}$ in the winter is also favoured by people

\footnotetext{
${ }^{2}$ Pleasure: Positive experience, a form of satisfaction consorted by pleasant mood, and good general feelings
} 
with no illnesses. The establishment not only provides bathing in the thermal water of Hévíz Lake, but also in the 7 pools of the Thermal Baths.

The survey included questions concerning motivation. After the exclusion of the 19 respondents having both medical- and wellness motivations ( 5 in the Thermal Baths, and 14 at the Thermal-Lake), the analysis of 281 questionnaires at the two locations resulted in the following clientele proportions: at the Bath Pools, $71.3 \%$ of respondents were medical tourists, while at the Hévíz Thermal Lake 76.1\% were wellness tourists. (Fig. 1).

Figure 1 Distribution of medical- and wellness guests at the two service locations (Bath Pools and Thermal Lake)

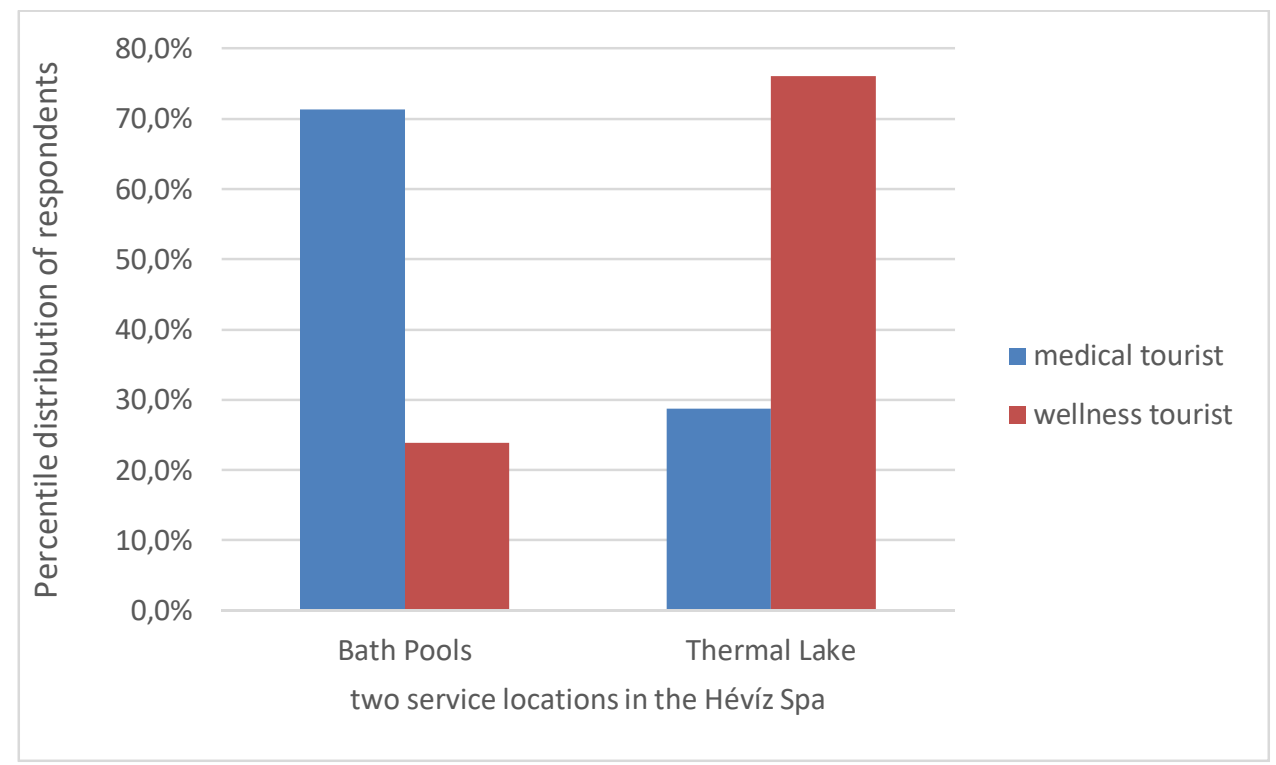

Source: Author's own results

Altogether, 58.4\% (164 people) of the visitors of Hévíz Spa are medical tourists struggling with illness, and 41.6\% (117 people) are wellness tourists, who visited the spa complex for prevention purposes, experience or just for active swimming activities. Further on, I present the outcomes of the quality, satisfaction, and loyalty investigations performed on this medical and wellness tourist clientele.

In case of medical- and wellness tourists, the research tries to find the answers to the following hypotheses:

H1: Service quality perceived by the clients has a positive correlation with guest satisfaction.

$\mathrm{H} 2$ : Guest satisfaction has a positive correlation with the willingness to return.

$\mathrm{H}_{3}$ : Satisfaction and recommendation willingness are positively correlated.

$\mathrm{H}_{4}$ : Guest satisfaction and positive word of mouth have a positive correlation.

$\mathrm{H}_{5}$ : Guest satisfaction and negative word of mouth have a negative correlation. 
Lőke, Z.

\section{RESULTS}

\section{Quality-Satisfaction analysis}

In the course of empirical research, quality was measured by SERVQUAL questions adapted to a spa. Guest satisfaction was enquired in three dimensions (E1, E2, E3). For the testing of quality-satisfaction correlations known for specialized literature, both in case medical- and wellness tourists I have compared the average of the replies given to SERVQUAL quality questions by each respondent to the replies concerning the dimension of satisfaction, all of which have been asked on a 5-stage Likert-scale. In case of all of the variables, correlation calculations resulted in an outcome significant on 0.01 level, which shows a medium strength, positive relationship between the quality and satisfaction opinions of both medical- and wellness tourists (Tab. 3). In case of wellness tourists, Pearson's correlation coefficient is 0.559 concerning satisfaction based on overall impressions (E3), 0.486 when asked about whether the time spent in the spa caused pleasure (E2), and 0.412 concerning the satisfaction dimension of fulfilment of preliminary expectations (E1). In case of medical tourists, Pearson's correlation coefficients are higher (0.510-0.724), confirming an even closer relationship between quality and satisfaction. Pearson's correlation values testify about medium strength relationships concerning preliminary expectations (E1) and pleasure (E2), while the 0.724 Pearson's correlational value of satisfaction based on overall impressions shows a strong relationship. Thus, $\mathrm{H}_{1}$ hypothesis is confirmed both in case of medical- and wellness clientele, as those ranking quality performance of the provider higher are also more satisfied, confirming a positive relationship that is already quite well-known from the works of Cronin \& Taylor (1992), and Anderson, Fornell, \& Lehmann (1994).

Table 3 Pearson's correlational coefficients of the investigation of relations between quality and satisfaction

\begin{tabular}{|l|c|c|}
\hline \multirow{2}{*}{$\begin{array}{l}\text { Pearson's correlational coefficient with two-sided } \\
\text { trial }\end{array}$} & $\begin{array}{c}\text { Performance average of service quality } \\
\text { factors, as a variable }\end{array}$ \\
\cline { 2 - 3 } & Medical tourist & Wellness tourist \\
\hline $\begin{array}{l}\text { E1. How much do you agree that your preliminary } \\
\text { expectations towards the service provider are fulfilled? }\end{array}$ & $0.560^{* *}$ & $0.412^{* *}$ \\
\hline $\begin{array}{l}\text { E2. How much do you agree that the time spent at the } \\
\text { Hévíz Spa was a pleasure to you? }\end{array}$ & $0.510^{* *}$ & $0.486^{* *}$ \\
\hline $\begin{array}{l}\text { E3. According to overall impressions, how satisfied are } \\
\text { you with the Spa? }\end{array}$ & $0.724^{* *}$ & $0.559^{* *}$ \\
\hline$* *$ significant value at $1 \%$ & \\
Source: Author's own results
\end{tabular}




\section{Empirical examination of satisfaction and loyalty}

The survey question concerning $\mathrm{H}_{2}$ hypothesis, testing willingness to return was "How much is the possibility of your return to Héviz Spa?" (L1), which I have compared with three satisfaction dimensions.

The correlational coefficients $(0.365-0.524)$ of medical tourists confirmed a medium positive connection (Tab. 4) on the significance level of $1 \%$. The strongest connection with medical tourists' willingness to return was shown in case of a joyful stay at Hévíz (correlational coefficient 0.524$)$.

Table 4 Pearson's correlational coefficients of the relations between satisfaction and loyalty variables

\begin{tabular}{|c|c|c|c|c|c|c|}
\hline \multirow[t]{3}{*}{$\begin{array}{c}\text { Pearson's correlational } \\
\text { coefficient with two- } \\
\text { sided trial }\end{array}$} & \multicolumn{2}{|c|}{$\begin{array}{l}\text { E1. How much do } \\
\text { you agree that your } \\
\text { preliminary } \\
\text { expectations towards } \\
\text { the service provider } \\
\text { are fulfilled? }\end{array}$} & \multicolumn{2}{|c|}{$\begin{array}{l}\text { E2. How much do } \\
\text { you agree that the } \\
\text { time spent at the } \\
\text { Hévíz Spa was a } \\
\text { pleasure to you? }\end{array}$} & \multicolumn{2}{|c|}{$\begin{array}{l}\text { E3. According to } \\
\text { overall impressions, } \\
\text { how satisfied are you } \\
\text { with the Spa? }\end{array}$} \\
\hline & Medical & Wellness & Medical & Wellness & Medical & Wellness \\
\hline & \multicolumn{2}{|c|}{ tourist } & \multicolumn{2}{|c|}{ tourist } & \multicolumn{2}{|c|}{ tourist } \\
\hline $\begin{array}{l}\text { L1. What is the } \\
\text { possibility of a return } \\
\text { to the spa or the } \\
\text { medical lake of Hévíz } \\
\text { Spa? }\end{array}$ & $0.365^{* *}$ & 0.159 & $0.524 * *$ & $0.584 * *$ & $0.428 * *$ & $0.257 * *$ \\
\hline $\begin{array}{l}\text { L2. What is the } \\
\text { possibility r of } \\
\text { recommending Hévíz } \\
\text { Spa to your friends or } \\
\text { family? }\end{array}$ & $0.292 * *$ & 0.146 & $0.437 * *$ & $0.636^{* *}$ & $0.363 * *$ & $0.248 * *$ \\
\hline $\begin{array}{l}\text { L3. What is the } \\
\text { possibility of reporting } \\
\text { positively to others } \\
\text { about Hévíz Spa? }\end{array}$ & $0.504 * *$ & $0.248 * *$ & $0.565^{* *}$ & $0.636^{* *}$ & $0.479 * *$ & $0.340 * *$ \\
\hline $\begin{array}{l}\text { L4. What is the } \\
\text { possibility } \\
\text { complaining to others if } \\
\text { you'd have problems } \\
\text { with the services? }\end{array}$ & 0.011 & 0.034 & -0.070 & -0.004 & -0.037 & -0.027 \\
\hline
\end{tabular}

Source: Author's own results

Thus, concerning medical tourists $\mathrm{H}_{2}$ hypothesis has been confirmed, in their case, there is a positive relation between satisfaction and willingness to return. As further aspects of loyalty, I have examined whether satisfaction increases recommendation and positive word of mouth, and also the possible level of client complaints upon experiencing problems. The questions included in the survey were: "What is the possibility of recommending Héviz Spa to your friends 
or family?", "What is the possibility of reporting positively to others about Héviz Spa?" The issue of negative word of mouth was important for me, because word of mouth is not necessarily positive. The question concerning negative word of mouth, "What is the possibility of complaining to others if you'd have problems with the services?" (L4) has not shown significant relationship with any other factors (Tab. 4), thus it is dismissed. In case of the metric variables of recommendation of the spa for friends and family (L2) and positive word of mouth (L3) even by e-WOM towards a wide community - in case of medical tourists there is a relationship with satisfaction dimensions, being significant at level 0.01. Pearson's correlational coefficient confirms a positive and medium strength relationship at each of the cases (Tab. 4). In the light of the above facts, in case of medical tourists $\mathrm{I}$ accept $\mathrm{H}_{3}$ and $\mathrm{H}_{4}$ hypotheses confirmed, concerning relationships between satisfaction and recommendations, as well as concerning satisfaction and positive word of mouth (Fig. 2).

Figure 2 Synoptic figure about the outcomes of satisfaction and loyalty relation investigations of medical tourists
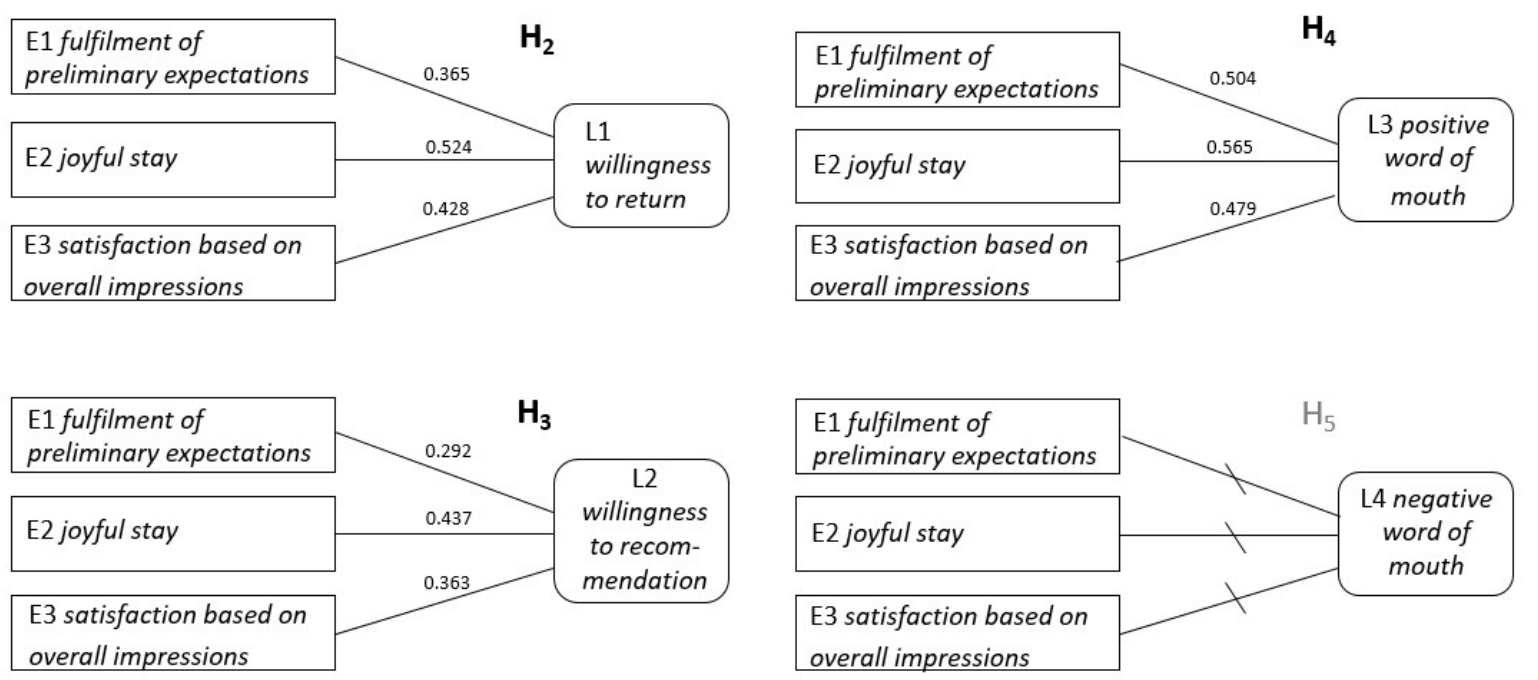

Source: Author's own results

In case of wellness tourists - similarly to medical tourists - $1 \%$ significant correlation with all three satisfaction dimensions was only confirmed concerning positive word of mouth (L3) loyalty factor (Tab. 4). Pearson's correlational coefficients inform us about medium strength positive relationships. According to this, $\mathrm{H}_{4}$ hypothesis between satisfaction and positive word of mouth was confirmed in case of wellness tourists. Amongst them, L3 loyalty factor also shows the strongest connection with a joyful stay at Héviz (E2), even exceeding the 0.565 relation strength of medical tourists with its 0.636 correlation value. In this aspect, wellness tourists confirm an even stronger relationship between satisfaction resulting in a delightful 
mood and pleasant overall feelings, and the willingness to tell others positively about the spa. However, in case of wellness tourists, concerning willingness to return (L1) and willingness to recommend (L2), satisfaction-loyalty correlations are not as obvious as for medical tourists, since statistically proven relations only stand for two satisfaction dimensions (Tab. 4) These two are joyful stay (E2) and satisfaction based on overall impressions (E3), where correlational coefficient values between $0.248-0.636$ confirm a medium strength positive relationship. Thus, concerning wellness tourists, $\mathrm{H}_{2}$ and $\mathrm{H}_{3}$ hypotheses are only partially confirmed (Fig. 3). In case of wellness tourists of the spa, fulfilment of preliminary expectations (E1) satisfaction dimension is neither related to willingness to return, nor to willingness to recommend loyalty factors. Similarly to medical tourists, negative word of mouth has not shown significant relationship with any satisfaction factors.

Figure 3 Synoptic figure about the outcomes of satisfaction and loyalty relation investigations of wellness tourists
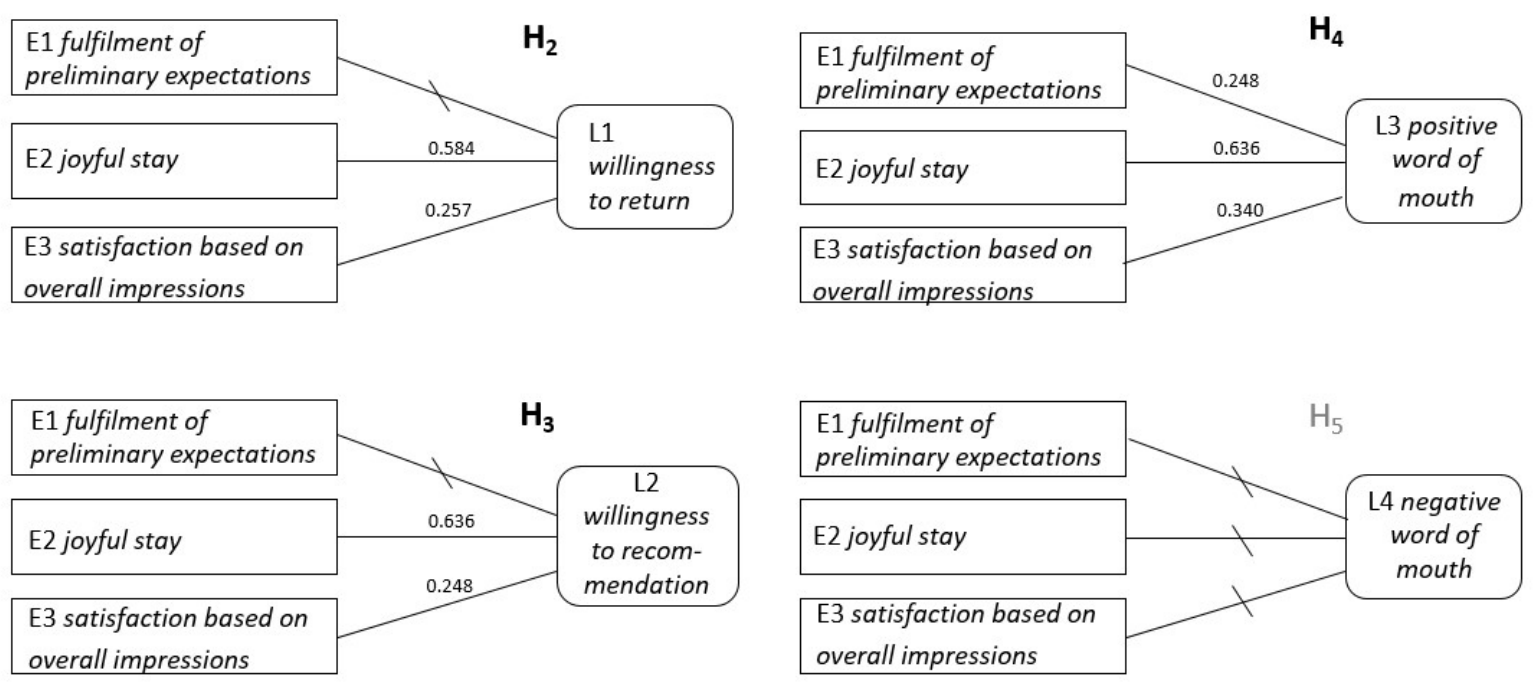

Source: Author's own results

In order to identify the factors affecting the loyalty of the dual clientele of the spa, I have used regression analysis to examine the effects of variables upon consumer loyalty. In case of medical tourists, a multi-variable linear regression model was constructed for all three loyalty factors. Joyful stay at Hévíz has a significant influence, complemented by satisfaction based on overall impressions being the other variable having a significant effect - although only with 5\% level concerning willingness to recommend (Tab. 5). 
Table 5 Regression analysis results of medical tourists for the loyalty dimensions of willingness to return, willingness to recommend and positive word of mouth

\begin{tabular}{|c|c|c|c|c|}
\hline Independent variable & Beta & Sig. & $\mathbf{r}^{2}$ & SEE \\
\hline & \multicolumn{4}{|c|}{ L1 willing to return } \\
\hline E2 The time spent at Hévíz Spa caused pleasure & 0.413 & 0.000 & \multirow[b]{2}{*}{0.306} & \multirow[b]{2}{*}{0.5001} \\
\hline $\begin{array}{l}\text { E3 How satisfied are you with the spa, based on your overall } \\
\text { impressions? }\end{array}$ & 0.210 & 0.009 & & \\
\hline & \multicolumn{4}{|c|}{ L2 willing to recommend } \\
\hline E2 The time spent at Hévíz Spa caused pleasure & 0.340 & 0.000 & \multirow[b]{2}{*}{0.215} & \multirow[b]{2}{*}{0.4090} \\
\hline $\begin{array}{l}\text { E3 How satisfied are you with the spa, based on your overall } \\
\text { impressions? }\end{array}$ & 0.184 & 0.030 & & \\
\hline & \multicolumn{4}{|c|}{ L3 would tell positively } \\
\hline E2 The time spent at Hévíz Spa caused pleasure & 0.433 & 0.000 & \multirow[b]{2}{*}{0.364} & \multirow[b]{2}{*}{0.4310} \\
\hline $\begin{array}{l}\text { E3 How satisfied are you with the spa, based on your overall } \\
\text { impressions? }\end{array}$ & 0.251 & 0.001 & & \\
\hline
\end{tabular}

Source: Author's own results

The relatively low (between 0.215-0.364) determination coefficient $\left(\mathrm{r}^{2}\right)$ marks at each of the three cases that further non-investigated factors can also influence dependent variable. Beta values show importance, which suggests that a joyful stay at Hévíz has a more (than 1.5 times) authoritative effect than satisfaction of overall impressions. All of this is consistent with the opinions of Zeithaml (2000), Kenesei and Kolos (2007), who suggest that in order to keep competitive advantage it is not enough if a service provider pursues customer satisfaction, but clients also have to experience pleasure while being impressed with a positive service performance exceeding their expectations until the emotional state of fascination!

In case of wellness tourists, in all of the three cases, a single-variable model was constructed, suggesting that the pleasure indicators of the time spent at Hévíz Spa has the most significant effect (Tab. 6) on the investigated loyalty factors.

Table 6 Regression analysis results of wellness tourists for the loyalty dimensions of willingness to return, willingness to recommend and positive word of mouth

\begin{tabular}{|l|c|c|c|c|}
\hline \multicolumn{1}{|c|}{ Independent variable } & Beta & Sig. & $\mathbf{r}^{2}$ & \multicolumn{1}{c|}{ SEE } \\
\hline & \multicolumn{4}{|c|}{ L1 willing to return } \\
\hline E2 The time spent at Hévíz Spa caused pleasure & 0.584 & 0.000 & 0.341 & 0.5551 \\
\hline & \multicolumn{4}{|c|}{ L2 willing to recommend } \\
\hline E2 The time spent at Hévíz Spa caused pleasure & 0.636 & 0.000 & 0.405 & 0.5143 \\
\hline & \multicolumn{4}{|c|}{ L3 would tell positively } \\
\hline E2 The time spent at Hévíz Spa caused pleasure & 0.636 & 0.000 & 0.404 & 0.5314 \\
\hline
\end{tabular}

Source: Author's own results

When compared to medical tourist, the models of wellness tourists call forth higher determination coefficients. Determination coefficients at the regression models of 
recommendation (L2) and positive word of mouth (L3) are $\mathrm{r}^{2}=0.404-0.405$, which signifies that $40 \%$ of the regression relations can be explained by the joyful stay at Hévíz satisfaction dimension.

\section{CONCLUSIONS AND SUGGESTIONS}

Although quality is a subjective judgement of values (Veres, 2009), the positive relationship between quality and satisfaction, well known from vocational literature (Cronin \& Taylor, 1992; Anderson, Fornell, \& Lehmann, 1994) is also confirmed by this present research concerning both medical- and wellness tourists.

My other purpose was to explore satisfaction-loyalty relations among the medical- and wellness tourists of the spa, which, according to specialized literature, are of not so obvious nature. On one hand, loyalty is faithfulness, thus I have examined willingness to return. Loyal clients are committed to the provider; thus they return, producing more profit in the future, and beyond that they can help to get potential new guests; that is why I formulated the separate question in the survey "What is the possibility of recommending Héviz Spa to your friends or family?" Another positive increment of loyal guests that they spread good news about the provider, which is an important and credible source of information especially in case of otherwise risky intangible services, as consumers primarily lean on their previous experiences as well as the opinions of their friends and relatives. Beyond previous face to face relations, by the help of internet a new alternative has opened up in informational society: e-WOM blogging, sharing - which can reach out to wide audiences. That is why I included the question "What is the possibility of reporting positively to other about Héviz Spa?" in the survey.

In case of medical tourists, the positive relationship concerning the loyalty dimensions of satisfaction, willingness to return, willingness to recommend, and positive word of mouth has been confirmed. Surprisingly - not only concerning wellness tourist, but medical tourists too - in case of all three factors of loyalty, joyful stay at Hévíz, namely the satisfaction dimension of "pleasure" had the highest level of correlation.

In case of wellness tourists, the fulfilment of preliminary expectations satisfaction dimension is only related to positive word of mouth loyalty factor. The rest of satisfaction-loyalty correlations are similar to the ones seen in case of medical tourists. Concerning wellness tourists, all there investigated loyalty factors have the closest correlation with a joyful stay at Héviz, their correlational values even exceeding the ones seen at medical tourists. In this regard, in case of wellness tourists, the correlation between satisfaction resulting in delightful mood 
with good overall feelings and loyalty is even stronger. This is consistent with the conception of wellness itself, as the expression "wellness" is an artificial word formulated by Dunn (1959) by the unification of the expressions "well-being" and "wholeness". In wellness tourism people holistically pursue the harmonic state of body-spirit-soul (Dunn 1961), which is best covered by a joyful stay satisfaction dimension.

Propitious recommendation willingness and positive word of mouth of a satisfied clientele is highly beneficial. However, word of mouth can also be negative, that is why I considered important to include the question "What is the possibility of complaining to others if you'd have problems with the services?" in the questionnaire. Negative word of mouth can be very deteriorative, and usually negative news also spread faster than positive. It would have been a good news to the provider if in the dimensions of satisfaction and negative word of mouth a reverse relationship would have been confirmed with a negative correlational value. However, in this present research, there is no proof of statistical relationship between satisfaction and negative word of mouth concerning neither medical-, nor wellness tourists. Further research of this issue of negative word of mouth could be expedient, by creating several sub-questions aiming to find out whether people would only complain to others even in a form of e-WOM, or would they let the provider know about their complaints, thus creating an opportunity to fix the given shortcomings. In this latter case the service provider would have the chance to correct the issue, as from Veres (2009) we already know that complaints are created when the clients are dissatisfied, no matter whether they give voice to their discontent or not.

Upon investigating the factors affecting the loyalty of medical- and wellness tourists with regression analysis, in consistence with the outcomes of Zeithaml (2000), Kenesei and Kolos (2007), the significance of pleasure and a joyful stay has been confirmed. According to the multi-variable model of medical tourists, the variable of pleasure (joyful stay) is more authoritative to loyalty than contentment with overall impressions. On the other hand, in case of wellness tourists, a single-variable model was constructed, suggesting that the satisfaction dimension of pleasure can explain $40 \%$ of recommendation and positive word of mouth regression relationships and $36 \%$ of willingness to return. This is consistent with the opinion of several researchers (Zeithaml, 2000; Kenesei \& Kolos, 2007, Löke, 2019), who suggest that pursuing guest satisfaction is not enough to gain advantage in competition, but clients also have to experience pleasure while being impressed with a positive service performance exceeding their expectations until the emotional state of fascination. There is a known definition of satisfaction determining it as the pleasure or disappointment created as the resultant of the expected and experienced services (Kotler \& Keller, 2012). No wonder that today the purpose 
of providers goes beyond satisfaction in pursue of providing a joyful experience. The spa also has to pursue this, as healing, regeneration and recreation in a delightful atmosphere is more efficient!

The relatively low $(0.215-0.405)$ determination coefficients of the regression models of medical and wellness tourists signify that beyond the examined independent variables there can be other factors - untouched by this present research - affecting the dependant variables of loyalty, which in our case are willingness to return, willingness to recommend, and positive word of mouth. Thus, it would be expedient to continue this research in order to explore these other factors affecting the loyalty of spa guests.

\section{REFERENCES}

Al-alak, B. A., \& EL-refae, G. A. (2012). The Relationships between Service Quality, Satisfaction, and Behaviroal Intentions of Malaysian Spa Center Customers. International Journal of Business and Social Science, 3(1), 198-205.

Anderson, E. W., Fornell, C., \& Lehmann, D. R. (1994). Customer satisfaction, market share, and profitability: Findings from Sweden. Journal of Marketing, 58(3), 53-66.

Bacsi, Z., \& Kovács, E. (2016). Managing health tourism destinations: Theory and Empirical Research in Hungary (p. 122). Scholar's Press, Saarbrücken, Deutschland.

Bilgihan, A., Madanoglu, M., \& Ricci, P. (2016). Service attributes as drivers of behavioral loyalty in casinos: the mediating effect of attitudinal loyalty. Journal of Retailing and Consumer Services, 31, 14-21.

Brown, W. S., Gummersson, E., Edvardsson, B., \& Gustavsson, B. (1991). Service Quality. Lexington Books. New York.

Canny, I. U. (2013). An empirical investigation of service quality, tourist satisfaction and future behavioral intentions among domestic local tourist at Borobudur temple. International Journal of Trade, Economics \& Finance, 4(2), 86-91.

Cheverton, P. (2005). A márkaimázs felépitése. Nélkülözhetetlen útmutató a márkamenedzsmenthez. [Building a brand image. Indispensable guide to brand management. - In Hungarian] Pécsi Direkt Kft Alexandra Kiadója.

Cronin, J. J., Brady, M. K., \& Hult, T. M. (2000). Assessing the effects of quality, value, customer satisfaction on consumer behavioral intentions in service. Journal of Marketing. 59(1), 78-94.

Cronin, J. J., \& Taylor, S. A. (1992). Measuring service quality: A reexamination and extension. Journal of Marketing. 56(3), 55-68.

Csordás, T., Markos-Kujbus, É., \& Ásványi, K. (2018). „A gyerekeim imádják, ezért én is imádom” - Családbarát hotelek fogyasztói percepciói online értékelések alapján. [„,My kids love it, so do I" - Customer perceptions of family-friendly hotels based on online evaluations. - In Hungarian] Turizmus Bulletin. 17(1), 17-28.

Dunn, H. L. (1959). High-Level Wellness for Man and Society. American Journal of Public Health, 49(6), 786-792.

Dunn, H. L. (1961). High level wellness. Washington, DC: Mt Vernon.

Edwardsson, B., Johnson, M. D., Gustafsson, A., \& Stranvik, T. (2000). The effects of satisfaction and loyalty on profits and growth: products versus services. Total Quality Management. 11(7), 917-927. 
Fisk, R. P., Brown, S. W., \& Bitner, M. J. (1993). Tracking the evolution of the services marketing literature. Journal of Retailing. 69(1), 61-103.

Grönholdt, L., Martensen, A., \& Kristensen, K. (2000). The relationship between customer satisfaction and loyalty: cross-industry differences. Total Quality Management. 11(4-6), 509-514.

Grönroos, C. (1998). Marketing services: the case of a missing product. Journal of Business and Industrial Marketing. 13(4), 322-338.

Hetesi, E. (2002). Új dimenziók a lojalitás mérésében. [New dimensions in measuring loyalty. In Hungarian] Marketing \& Menedzsment. 2002(4), 35-41.

Hetesi, E. (2003). A minőség, az elégedettség és a lojalitás mérésének problémái a szolgáltatásoknál, és azok hatása a jövedelmezőségre. [Measurement problems of quality, contentment and loyalty at services, and their effect to profitability. - In Hungarian] Marketing \& Menedzsment. 2003(5), 42-50.

Hofmeister Tóth, Á., Simon, J., \& Sajtos, L. (2003). Fogyasztói elégedettség. [Customer satisfaction - In Hungarian]. Alinea Kiadó, Budapest.

Jones, T. O., \& Sasser, Jr. W. E. (1995). Why satisfied customer defect? Harvard Business Review, 73(6), 88-99.

Kaya, O. (2018). Exploring the Satisfaction and Dissatisfaction Factors Derived from Food and Beverage Services of Thermal Hotels. DETUROPE The Central European Journal of Regional Development and Tourism, 10(3), 143-161.

Kenesei, Z., \& Kolos, K. (2007). Szolgáltatásmarketing és-menedzsment. [Service marketing and management - In Hungarian]. Alinea Kiadó, Budapest.

Khan, F., Yusoff, R. M., \& Kakar, P. (2017). Impact of service quality and customer satisfaction on tourism industry. Journal of Advanced Research in Social and Behavioural Sciences, 6(2), 146-155.

Kotler, P., \& Keller, K. L. (2012). Marketingmenedzsment. [Marketing management Hungarian translation]. Akadémia Kiadó, Budapest.

Kumar, V., Pozza, I. D., \& Ganesh, J. (2013). Revisiting the satisfaction-loyalty relationship: Empirical generalizations and directions for future research. Journal of Retailing, 89(3), 246-262.

Lee, J. H., Kim, H. D., \& Sagas, M. (2011). The influence of service quality on satisfaction and intention: a gender segmentation strategy. Sport Management Review. 14, 54-63.

Lewis, R. C., \& Booms, B. H. (1983). The marketing aspectsof service quality in Berry, L., Shostack, G. and Upah, G. (eds.), Emerging perspectives on services marketing, American Marketing Association Chicago, 99-104.

Lőke, Z. (2019): A minőség-elégedettség-lojalitás mérésének módszerei és tapasztalatai egy hazai gyógyfürdőben. [Measurement methods and observations of quality-contentment correlations in a domestic spa - In Hungarian] Turizmus Bulletin. 19(2), 15-23.

Lőke, Z., Kovács, E., \& Bacsi, Z. (2018). Assessment Of Service Quality And Consumer Satisfaction In A Hungarian Spa. DETUROPE The Central European Journal of Regional Development and Tourism, 10(2), 124-146.

Malhotra, N. K. (2002). Marketingkutatás. [Marketing research - Hungarian translation]. KJKKERSZÖV Jogi és Üzleti Kiadó Kft. Budapest.

Martensen, A., Grönholdt, L., \& Kristensen, K. (2000). The drivers of customer satisfaction and loyalty: cross industry findings from Denmark. Total Quality Management. 11(4-6), 544553.

Nagy, Á. A., Kemény, I., Simon, J., \& Kiss, V. (2015). Az online szájreklám alapjául szolgáló magatartás és az elégedettség kapcsolata. [Relationship between behaviours composing the base of online word of mouth and contentment. - In Hungarian] Marketing \& Menedzsment. 2015(4), 18-35. 
Oliver, R. L. (1999). Whence Consumer Loyalty? Journal of Marketing. 63, Special Issue, 3344.

Parasuraman A., Zeithaml, A., \& Berry L. (1985). A Conceptual Model of Service Quality and Its Implications for Future Research. Journal of Marketing. 49(47). In: Swarbrooke, J., \& Horner, S. (2007): Consumer Behaviour in Tourism. Second edition. Published by Elsevier Ltd. Oxford, UK.

Parasuraman, A., Zeithaml, V. A., \& Malhotra, A. (2005). E-S-QUAL: A Multiple-Item Scale for Assessing Electronic Service Quality. Journal of Service Research. 7(3), 213-233.

Picón, A., Castro, I., \& Roldán, J. L. (2014). The relationship between satisfaction and loyalty: A mediator analysis. Journal of Business Research, 67(5), 746-751.

Powers, T. L., Jack, E. P., \& Choi, S. (2019). Is store or service satisfaction more important to customer loyalty? Marketing Management Journal, 29(1) Springs, 16-30.

Reicheld, F. F. (1996). The Loyalty Effect. Boston, MA: Harvard Business School Press.

Reicheld, F. F., \& Sasser, W. E. (1990). Zero Defections: Quality Comes to Services. Harvard Business Review, 68(5), 105-111.

Sajtos, L., \& Mitev, A. (2007). SPSS Kutatási és adatelemzési kézikönyv. [SPSS Research and data analysis handbook - In Hungarian]. Alinea Kiadó, Budapest.

Simay, A. E. (2013). A fogyasztói elégedettség, a fogyasztói bizalom és a fogyasztói lojalitás összefüggéseinek vizsgálata a magyar mobil telekommunikációs szolgáltatások piacán. címü Ph.D. értékezés. [Investigation of the correlations of consumer contentment, consumer confidence and consumer loyalty on the market of Hungarian telecommunication services, Ph.D dissertation - In Hungarian] Corvinus Egyetem Budapest, 26. Retrieved from http://phd.lib.uni-corvinus.hu/748/1/Simay_Attila_dhu.pdf

Škodová Parmová, D., Dvořáková Líšková, Z., \& Kain, R. (2018). Raising the Quality of Tourism Firms - Case study from the Czech Republic. In: Bezpartochnyi, M. Transformational processes the development of economic systems in conditions of globalization: scientific bases, mechanisms, prospects. $1^{\text {st }}$ ed. Riga, Latvia: ISMA University, Riga: Landmark SIA, 2018. 233-241.

Tian-Cole, S. T., Crompton, J. K., \& Willson, V. L. (2002). An empirical investigation of the relationships between service quality, satisfaction and behavioral intentions among visitors to wildlife refuge. Journal of Leisure Research. 34, 1-24.

Trif, S. M. (2013). The influence of overall satisfaction and trust on customer loyalty. Management \& Marketing Challenges for the Knowledge Society, 8(1), 109-128.

Veres, Z. (2009). A szolgáltatásmarketing alapkönyve. [The basic book of sercive marketing In Hungarian]. Akadémiai Kiadó Zrt., Budapest.

Vollmer, I., Johnson, M., Herrmann, A., \& Huber, F. (2000). The Loyalty of Dissatisfied Customers: Determinants and Implications". XXV Annual Colloquium on Research in Econimic Psychology and SABE 2000 Conference, Baden, Vienna/Austria

Zeithaml, V. A., Berry, L. L., \& Parasuraman, A. (1988). Communication and Control Process in the Delivery of Service Quality. Journal of Marketing. 52(April), 35-48.

Zeithaml, V. A. (2000). Service Quality, Profitability, and the Economic Worth of Customers: What We Know and What We Need to Learn. Journal of the Academy of Marketing Sciences. 28(1), 67-85. 